\title{
Observations of a stratospheric aerosol veil from a tropical volcanic eruption in December 1808: is this the Unknown $\sim 1809$ eruption?
}

\author{
A. Guevara-Murua ${ }^{1,2}$, C. A. Williams ${ }^{2,3}$, E. J. Hendy ${ }^{1,2}$, A. C. Rust $^{1,2}$, and K. V. Cashman ${ }^{1,2}$ \\ ${ }^{1}$ School of Earth Sciences, Wills Memorial Building, University of Bristol, Bristol BS8 1RJ, UK \\ ${ }^{2}$ Cabot Institute, Royal Fort House, University of Bristol, Bristol BS8 1UJ, UK \\ ${ }^{3}$ Department of Hispanic, Portuguese and Latin American Studies, School of Modern Languages, University of Bristol, \\ Bristol BS8 1TE, UK \\ Correspondence to: C. A. Williams (caroline.williams@bristol.ac.uk)
}

Received: 11 April 2014 - Published in Clim. Past Discuss.: 28 April 2014

Revised: 7 July 2014 - Accepted: 30 July 2014 - Published: 16 September 2014

\begin{abstract}
The Unknown eruption of 1808/1809 was the second most explosive $\mathrm{SO}_{2}$-rich volcanic eruption in the last two centuries, eclipsed only by the cataclysmic VEI 7 Tambora eruption in April 1815. However, no eyewitness accounts of the event, and therefore its location, or the atmospheric optical effects associated with its aerosols have been documented from historical records. Here we report on two meteorological observations dating from the end of 1808 that describe phenomena we attribute to volcanic-induced atmospheric effects caused by the Unknown eruption. The observations were made by two highly respected Latin American scientists. The first, Francisco José de Caldas, describes a stratospheric aerosol haze, a "transparent cloud that obstructs the sun's brilliance", that was visible over the city of Bogotá, Colombia, from 11 December 1808 to at least mid-February 1809. The second, made by physician José Hipólito Unanue in Lima, Peru, describes sunset after-glows (akin to well-documented examples known to be caused by stratospheric volcanic aerosols) from mid-December 1808 to February 1809. These two accounts provide direct evidence of a persistent stratospheric aerosol veil that spanned at least $2600 \mathrm{~km}$ into both Northern and Southern Hemispheres and establish that the source was a tropical volcano. Moreover, these observations confirm that the Unknown eruption, previously identified and tentatively assigned to February 1809 ( \pm 4 months) from analysis of ice core sulfate records, occurred in late November or early December 1808 (4 December $1808 \pm 7$ days). This date has important implications for the associated hemispheric climate impacts and temporal pattern of aerosol dispersal.
\end{abstract}

\section{Introduction}

The 1810s were the coldest decade and longest sustained period of below-average hemispheric and tropical temperatures in the last 500 years (e.g. Jones et al., 1995; Briffa et al., 1998; D' Arrigo et al., 2009). This decade is also notable for a clustering of climate forcing events that includes a period of low solar activity (the Dalton minimum; Eddy, 1976) and the Tambora eruption, Indonesia (climactic phase, 10 11 April 1815), one of the largest magnitude volcanic eruptions of the last millennium (VEI 7; Oppenheimer 2003). Large explosive volcanic eruptions inject massive amounts of sulfur dioxide directly into the stratosphere where it is rapidly oxidized and concentrated within a stratospheric sulfate aerosol layer (reviewed by Robock, 2000). Cooling of the troposphere and the Earth's surface occurs because the sulfate aerosols reduce surface solar insolation receipt by increasing atmospheric albedo and absorbing short-wave radiation (Robock, 2000). Thus the Tambora eruption has been linked directly to the year without a summer (1816), in which crops failed, and there were frosts and famine in Europe and North America (Stothers, 1984).

Global temperatures were cooling prior to the Tambora eruption, however, as illustrated by a $0.53{ }^{\circ} \mathrm{C}$ decrease in tropical sea surface temperatures between 1809 and 1810 (D'Arrigo et al, 2009). This temperature perturbation has also been attributed to a large tropical eruption that has been identified from volcanically derived sulfuric acid peaks in Greenland and Antarctica ice cores (Legrand and Delmas 1987; Dai et al., 1991; Moore 1991; Cole-Dai et al., 2009). 
As the source of this eruption has yet to be located, it has been termed either the $A D 1809$ eruption (Dai et al., 1991) or the Unknown eruption (Mosley-Thompson et al., 2003). The magnitude of this eruption has been inferred to be at least VEI 6, with an estimated stratospheric sulfuric acid $\mathrm{H}_{2} \mathrm{SO}_{4}$ loading of $53.74 \mathrm{Tg}$ (Gao et al., 2008) and stratospheric aerosol optical depth of between 0.198 (Crowley and Unterman, 2013) and 0.27-0.28 (Crowley et al., 2008; Arfeuille et al., 2014) based on sulfate deposition recorded in ice cores. This makes the c. 1809 Unknown eruption one of the most $\mathrm{SO}_{2}$-rich stratospheric tropical eruptions in the last 500 years: its sulfate contribution was half that of the Tambora eruption, but almost twice that of the Mt Pinatubo eruption (VEI 6, 1991), more than two times that of the Krakatau eruption (VEI 6, 1883), and more than three times the eruptions of Agung (VEI 5, 1963) and El Chichón (VEI 5, 1982; Gao et al., 2008). It is remarkable that a recent volcanic eruption of such intensity is absent from observation-based reconstructions of volcanic climate forcing (e.g. Lamb, 1970), but no eyewitness reports or contemporary observational documentation of the event have been found. For this reason, both the location and the timing of the eruption have been the source of much debate.

The debate about the eruption location has focused primarily on interpretations of a volcanic sulfate signal found in ice cores from both poles (Dai et al., 1991). This bi-polar signal, when combined with analysis of contemporary tephras (Kurbatov et al., 2006; Yalcin et al., 2006), led to the hypothesis that the Unknown eruption actually represented two separate high-latitude events (one volcano in each hemisphere). Further analysis, however, showed a sulfur isotopic anomaly in the ice core records that indicates a stratospheric source, and therefore a single low-latitude eruption (Cole-Dai et al., 2009). The timing of the eruption has also been a source of debate. The earliest date is between March and June 1808 . This date was proposed to explain both an abrupt negative anomaly in noon temperatures of two Malaysian records and evidence that the most extreme cooling anomaly in annually averaged tropical marine air temperatures $\left(20^{\circ} \mathrm{N}-20^{\circ} \mathrm{S}\right)$ occurred in 1809 (Chenoweth, 2001). The latest suggested date is February 1809 ( \pm 4 months), a time bracket that was determined using high-resolution dated ice core records from Antarctica and Greenland and the arrival in 1810 of excess sulfate in both Greenland and Antarctica ice cores, 72-77 months prior to the peak associated with the Tambora eruption in April 1815 (Cole-Dai et al., 2009).

Both the location and timing of an eruption will affect the eruption impacts. Distinguishing between an extratropical and tropical source is critical because the latitude determines the geographic distribution of both climatic and atmospheric effects. If a strong eruption (VEI 5 or greater) is located in the tropics, the stratospheric aerosol layer rapidly spreads zonally ( $>20 \mathrm{~m} \mathrm{~s}^{-1}$; Bluth et al., 1992) within the tropical pipe region around the equator (Plumb, 1996). Aerosol transport toward the poles occurs preferentially into the winter hemisphere (Trepte et al., 1993) when increased activity and breaking of planetary-scale Rossby waves in the mid-latitude stratosphere enables isentropic mixing and meridional transport (Brewer-Dobson circulation; Holton et al., 1995). Sulfate aerosols from tropical volcanic eruptions have been observed to form a stratospheric layer across the entire globe (e.g. following Mt Pinatubo, 1991) with an $e$-folding residence time of 1 year (Robock, 2000). In contrast, it is rare for stratospheric aerosols to reach the tropics following similarly strong high-latitude volcanic eruptions (Graf, 1992; Oman et al., 2005), due to rapid removal through both strong subsidence in the polar vortex and mid-latitude tropospheric folding (Hamill et al., 1997). Hence, the climatic effects of high-latitude stratospheric eruptions are restricted primarily to the extratropics, and to the hemisphere in which the eruption occurred (e.g. Oman et al., 2005; Schneider et al., 2009). The timing is critical because seasonality controls the hemispheric distribution of radiative impacts, dynamic responses and therefore climatic perturbations (Robock, 2000; Toohey et al., 2011). Although aerosols are preferentially transported into the winter hemisphere, temperature anomalies are predominantly determined by the amount of short-wave radiation that arrives at the Earth's surface and, therefore, impacts are greatest for the tropics and the summer hemisphere (Robock, 2000).

Aerosols from large volcanic eruptions also produce visible global atmospheric effects such as a haze that filters and refracts light (e.g. Symons, 1888; Stothers and Rampino, 1983; Stothers, 1999) and vivid sunset glows (Symons, 1888; Lamb, 1970; Deirmendjian, 1973). The haze is caused by concentrated layers of volcanic aerosols, within the troposphere or stratosphere depending on the altitude where the sulfate aerosols are injected, and can become widely dispersed (Stothers, 1999). The best-known example of a tropospheric dry fog is the one associated with the Laki Eruption (Iceland, 1783), which damaged crops and caused widespread health problems across western Eurasia and into the Arctic (Grattan and Brayshay, 1995; Stothers, 1996; Thordarson and Self, 2003). Historical documents also detail the visual effects of stratospheric volcanic haze. For example, global dispersal and optical impact of an upper atmosphere aerosol layer following the Krakatau eruption (Indonesia, 1883) was documented thoroughly in the report on the event edited by Symons (1888). The atmospheric effects from the Krakatau 27 August eruption were observed in the Atlantic Ocean within a week, for example:

"On 1 September, the Queen of Cambria in $9^{\circ} \mathrm{S} ., 28^{\circ} \mathrm{W}$., at 8 a.m., notices 'a peculiar thin haze in the air through which the sun is seen with a clearly defined circumference, and almost white in colour; at 8 p.m., stars dimly visible through haze'." (Archibald in Symons, 1888, p. 220).

Various ships reported the phenomena as it spread to circumnavigate the equator over a 2-week period:

"On 6 September, Eastern time, the same ship [the Papa], in $8^{\circ} 1^{\prime} \mathrm{N} ., 161^{\circ} 4^{\prime}$ W., remarks: 'the entire sky is covered by 
an even yellowish-red, high layer of cirro-stratus. The sun pierces through, but looks pale, as when seen through a blue glass, with sharply marked edge, nice for observations, well tolerable to the eye, without nimbus or halo. At night the stars were dimly visible'. Thenceforward we have with little intermission, accounts worded in very similar language, of the sky being 'covered with a light haze'; 'the sun, when green, stands out from a smoky sky', ... Together with the accompanying phenomena of the blue and green suns, it appeared after the first revolution of these round the globe, at higher latitudes than on its first journey." (Archibald in Symons, 1888, p. 221).

Perhaps the most common atmospheric disturbances described following large explosive eruptions are vivid sunsets, and in particular a prolonged twilight after-glow due to the enhanced forward scattering caused by the volcanic aerosols in the stratosphere (Symons, 1888; Deirmendjian, 1973). This phenomenon has been observed worldwide after recent major volcanic eruptions and reported in contemporary documents following historic events such as Awu (Indonesia, 1641), Katla (Iceland, 1660), Laki (Iceland, 1783), Tambora (Indonesia, 1815) and Krakatau (Indonesia, 1883) (e.g. Symons, 1888; Lamb, 1970). The colours of these sunsets are so distinctive that contemporary paintings have been used to estimate aerosol optical depths after major volcanic eruptions (e.g. Zerefos et al., 2007, 2014).

Here we present evidence of atmospheric disturbances that are drawn from the work of two of the most prominent Latin American scientists of the early 19th century, and published within a few years of the $\sim 1809$ Unknown eruption. We argue that these records of unusual meteorological events in Colombia and Peru can be used to constrain both the location and timing of the Unknown eruption. Importantly, the authors describe, in scientific terms, phenomena such as a stratospheric aerosol veil and sunset after-glows occurring from 11 December 1808 until February 1809. Together, the accounts suggest that these phenomena were produced by a single low-latitude stratospheric volcanic eruption that occurred in late November or early December 1808.

\section{Materials, methods and description of sources}

The first observation (reproduced in full in Appendix A) appeared in February 1809 in the Semanario del Nuevo Reyno de Granada, a periodical edited by Francisco José de Caldas, Director of the Astronomical Observatory of Santa Fe de Bogotá (Colombia). Published weekly from 1808 to 1810 , the Semanario's principal purpose was the diffusion of practical and scientific knowledge relating to the geography, demography, natural history and climate of what was one of Spain's principal colonial territories in the Americas. The second appeared as a footnote in the second edition of Peruvian physician José Hipólito Unanue's Observaciones sobre el clima de Lima y sus influencias en los seres organizados, en especial el hombre, published in Madrid in 1815 (extract reproduced in Appendix B). Bogotá and Lima, both capitals of Spanish viceroyalties, were important centres of intellectual activity and rigorous scientific research in the late 18th and early 19th centuries, and as Glick (1991) and others have shown, Caldas and Unanue were leading figures in their respective circles and disciplines (Appel, 1994; Nieto et al., 2005; Nieto Olarte, 2007; Zimmerer, 2006; Cushman, 2011). They shared a profound interest in the varied climates of the territories of their birth, in Unanue's case particularly due to his concern for understanding the impact of climate phenomena on human health (Cushman, 2011). As American-born Spaniards, they also became deeply engaged in long-standing debates, which gained renewed impetus under the influence of the European Enlightenment, regarding the alleged inferiority of the New World climate and its supposedly deleterious effects on its people, fauna and flora. This engagement with the science of the day required extensive investigations, for which they drew not only on their own work - as director of the Bogotá Observatory, for instance, Caldas established a regular programme of astronomical and meteorological observations (Caldas, 1912) - but also on that of a wide network of correspondents in towns and cities across modern-day Colombia and Peru. Their significance as scientists (and, in Caldas' case, as collaborator) were acknowledged by Alexander von Humboldt, whose own writings, many based on the results of his travels in Latin America between 1799 and 1804, are widely recognized as contributing to the development of modern geography, ecology and environmental sciences (Glick, 1991; Zimmerer, 2006; Cushman 2011).

To date, we have recovered no further observations of atmospheric disturbances in either Colombia or Peru in 18081809. In 1832, a description of the phenomena observed in Bogotá from December 1808 was presented to a meeting of the French Institute (attended by the physicist and astronomer François Arago) by the physician, naturalist and painter François Désiré Roulin, which was subsequently reported in The New Monthly Magazine and Literary Journal under the title "Atmospherical Phenomena in New Grenada" (reproduced in full in Appendix C). However, we know that Roulin took part in a scientific mission to Colombia in the 1820s (Humboldt, 2011), and since his version is so similar to that of Caldas (in both content and the order in which the various anomalies are enumerated), we are confident that it was Caldas' contribution to the 1809 Semanario that served as the source for the 1832 report, and that this is not an independent observation or verification.

\section{Results}

The report published by Caldas in February 1809 describes an anomalous thin upper atmospheric cloud in Bogotá (Colombia) that had been uniform and persistent since 


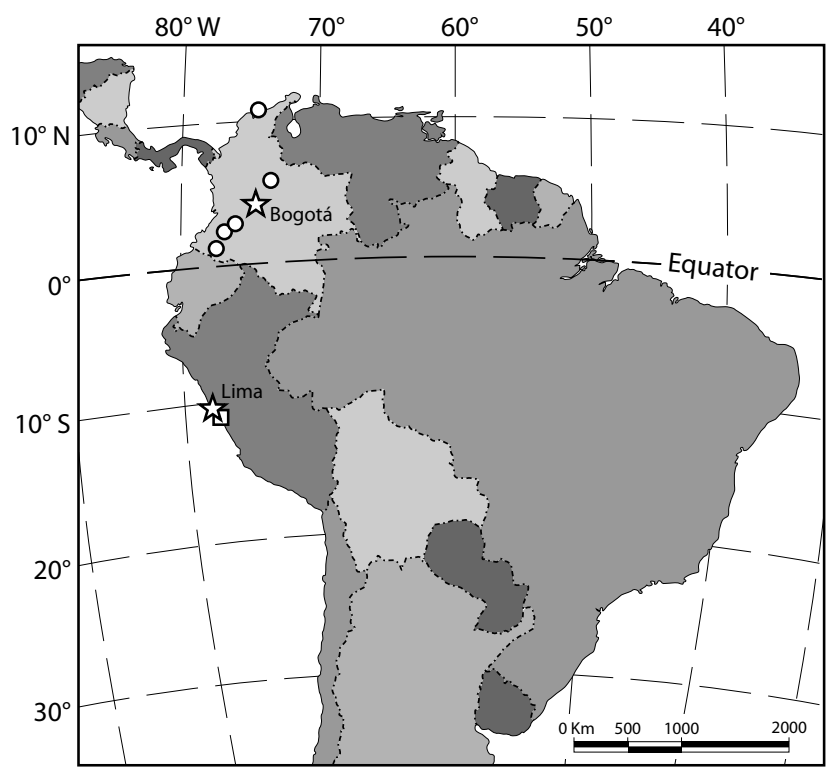

Figure 1. Map of South America indicating the six locations in Colombia reported by Caldas (1809) where the stratospheric aerosol veil had been observed from 11 December 1808 (circles: Pasto, Popayán, Neiva, Santa Marta, Tunja). The square shows the location of the district of Chorrillos, Lima, Peru, where after-glows were observed following sunsets from mid-December 1808 to February 1809 as reported by Unanue (1815).

11 December 1808 , and affected the visibility of the sky, the stars and the sun:

As of 11 December of last year, the disk of the sun has appeared devoid of irradiance, its light lacking that strength which makes it impossible to observe it easily and without pain. Its natural fiery colour has changed to that of silver, so much so that many have mistaken it for the moon. This phenomenon is very noticeable at sunrise, and particularly when the sun sets. When [the sun] is at its zenith, it shines more brightly and cannot be looked at with the naked eye. Near the horizon, it has been seen to take on a light rosy hue, [or] a very pale green, or a blue-grey close to that of steel. [...] The whole vault of the sky has been covered by a light cloud as widespread as it is transparent. [...] [Also] missing have been the emphatic coronas which are so frequently seen around the sun and the moon when those clouds that meteorologists know by the name of veil are present. The stars of the first, second and even the third magnitude have appeared somewhat dimmed, and those of the fourth and fifth have completely disappeared, to the observer's naked eye. This veil has been constant both by the day and by night...
This account resembles descriptions of volcanic-induced stratospheric haze, particularly in the shared emphasis on the effect of the aerosol cloud on the visibility of the sun, which changes its colour to silver, green or grey (reviewed in Symons, 1888). Caldas also records the anomalous colour of the sky, which we take to be particularly significant because of his familiarity with the use of the cyanometer (invented by Horace-Bénédict de Saussure; Lilienfeld, 2004), and the related discovery that the blueness of the sky is more intense at higher altitudes. Indeed, in a report on the instruments held by the Astronomical Observatory, published in the Semanario in February 1808, Caldas specifically made reference to the clarity and intense blueness of the sky over Bogotá. From the Observatory, he said, "the stars could be seen to shine with such clarity upon a sky so blue" as to be the envy of European astronomers (Obras de Caldas, pp. 274-275). Therefore, his observation that in Bogotá in late 1808 and early 1809 the sky had become so pale that it "corresponded to the lowest degrees of the cyanometer, and on some days appeared to be truly white" records a significant anomaly. Of equal importance is that the upper atmospheric veil Caldas observed in Bogotá between December 1808 and February 1809 was also reported from other parts of Colombia (Fig. 1), which led Caldas to suspect that it was even more widespread:

This phenomenon has been observed in Pasto, in Popayán, in Neiva, in Santa Marta, in Tunja and no doubt throughout the entire Viceroyalty. To a physicist it would not be at all surprising were it to be seen in all countries located within the tropics.

As Director of the Astronomical Observatory, Caldas was engaged in a range of activities, including meteorological readings of pressure, temperature, rainfall and cloudiness, which were also published in the Semanario. We reproduce some of the available data he published from January 1807 to July 1808 (Fig. 2) to demonstrate Caldas' experience and knowledge in relation to the climate anomalies he later describes; unfortunately the original records and measurements after July 1808 appear to be lost. The 1807 observations include the warmest day mean temperature and the coldest day mean temperature taken in the interior of the observatory for each month, the annual mean average taken in the exterior of the observatory, in addition to pressure, rainfall and number of rainy days. The 1808 observations (January to July) are compiled differently, and include the daily mean temperature for each month in the interior and the exterior of the observatory, pressure, rainfall, number of rainy days and cloudiness (Caldas, 1912). Air temperature measurements are subject to a number of biases, including thermometer exposure, and it is clear that Caldas is aware of this as he records both internal and external measurements. The external monthly average temperatures (obviously without the modern Stevenson-type screen) are warmer and more variable than the internal data by $3.3^{\circ} \mathrm{C}$ (Fig. 2). It is also 
apparent that all Caldas' measurements are too high, with the reported temperatures comparable or warmer than modern climatology (monthly average El Dorado Observatory of Bogotá, IDEAM and Fondo de Prevención y Atención de Emergencias, 2007). However, these measurements demonstrate that Caldas knew of the stability of seasonal and interannual air temperatures in Bogotá. Similarly, his reports of the number of rainy days per month (Fig. 2) demonstrate that January and February are consistently the driest months of the year in Bogotá, in agreement with modern rainfall seasonality (monthly average 1971-2004, El Dorado Observatory of Bogotá, IDEAM and Fondo de Prevención y Atención de Emergencias, 2007). So, although no meteorological measurements for December 1808 to February 1809 were published in the Semanario, Caldas was evidently continuing these measurement time series and could report with high confidence that these months were uncharacteristically cold for Bogotá:

We have experienced very cold mornings, far colder than should be the case in this city, given its altitude and geographic location. Many mornings the fields have been covered in ice, and we have all seen trees and other particularly sensitive crops damaged by frost. [...] the weather has been dry, and, intermittently, the southerly winds have been dominant, followed by periods of considerable calm.

The observation of regular frosts is also significant in comparison to modern climatology (Fig. 2). Although there is an increased likelihood for a frost event to occur in December, January and February, only 2-3 frost days are typically recorded in total for these 3 months at the El Dorado Observatory in Bogotá, and on average only three events a year (averaged over the period 1987-2007; Fig. 2 data reproduced from Márquez et al., 2008). Additionally, the southerly wind regime Caldas describes does not correspond to modern wind climatology for these three months, or for any season, instead the dominant winds are persistently and anomalously W/N/NE (Fig. 3; El Dorado Observatory in Bogotá; IDEAM and Fondo de Prevención y Atención de Emergencias, 2007).

We note that at the same time as Bogotá was experiencing the climatic anomalies described by Caldas, unusual optical effects at sunset were observed in the Chorrillos district of Lima, as recorded by the Peruvian physician Hipólito Unanue in the 1815 edition of his Observaciones sobre el clima de Lima y sus influencias en los seres organizados, en especial el hombre:

At sundown in the middle of the month of December, there began to appear towards the S.W, between cerro de los Chorrillos and the sea, an evening twilight that lit up the atmosphere. From a N.S. direction on the horizon, it rose towards its zenith in the form of a cone, [and] shone with a
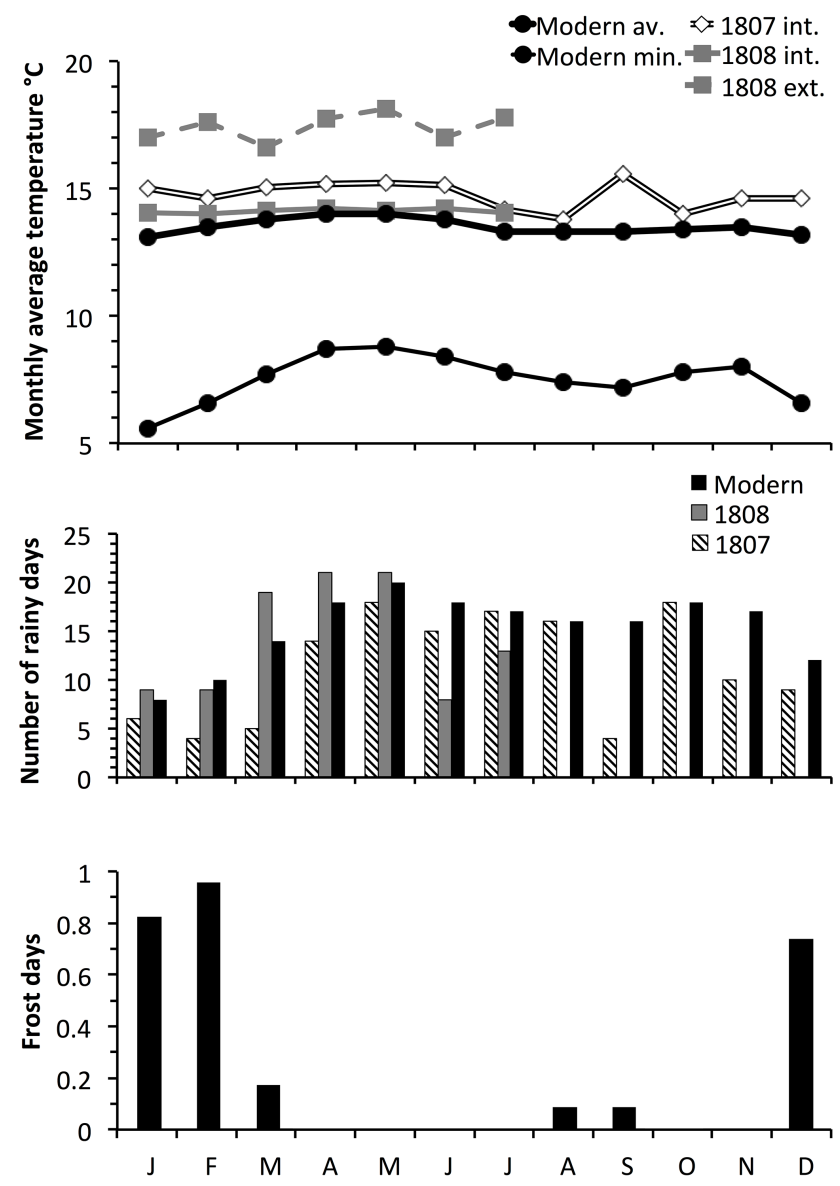

Figure 2. Meteorological data for the city of Bogotá, Colombia. Modern data (black) are from the El Dorado Observatory (IDEAM and Fondo de Prevención y Atención de Emergencias 2007; Márquez et al., 2008); 1807 and 1808 data as recorded by Francisco José de Caldas and published in the Semanario (Caldas, 1912; pp. 331-337 and 500). Top panel, monthly mean and minimum temperatures (black circles, climatological average for 19701980; white diamonds, interior average temperature for 1807; dark grey diamonds, interior and exterior temperatures for 1808). The 1807 and 1808 data were reported by Caldas in ${ }^{\circ} \mathrm{R}$ and have been converted to ${ }^{\circ} \mathrm{C}$. Middle panel shows the number of rainy days per month for January-December 1807, January-July 1808 and modern rainfall climatology for 1971-2004. Lower panel, average number of frost days per month over the period 1985-2007 (from Márquez et al., 2008).

clear light until eight [o'clock] at night, when it faded. This scene was repeated every night until the middle of February, when it vanished.

This phenomenon, known as a twilight glow, typically follows in the aftermath of strong volcanic eruptions (e.g. observations reported in Symons, 1888) with the prolonged afterglow caused by light scattering from stratospheric aerosols (Deirmendjian, 1973). These dates coincide with those mentioned by Francisco José de Caldas for the upper atmospheric veil in Colombia, suggesting that the same aerosol 
cloud was responsible for the sunset after-glow described by Hipólito Unanue in Peru. This cloud, therefore, spanned at least $2600 \mathrm{~km}$ (from Santa Marta, Colombia to Lima, Peru; Fig. 1) across both the Northern and Southern Hemispheres.

\section{Discussion}

We have presented two published sources from Colombia and Peru that describe anomalous atmospheric and meteorological conditions that started in mid-December (11 December in Bogotá) and lasted for more than 2 months. Taking into account the description of the upper atmospheric veil, the vivid sunset glow, the unexpectedly low temperatures and high frost frequency, as well as the consistent timing and duration of the observations, we propose that a stratospheric aerosol veil spread across equatorial Latin America from 11 December 1808. Here, we analyse the descriptions contained within the two accounts to provide supplementary insights regarding the nature and source of the upper atmospheric haze. We argue that the atmospheric phenomena described by Caldas and Unanue provide evidence for a stratospheric aerosol cloud caused by the Unknown eruption of 1808-1809.

There is good evidence from the careful and scientific description written by Caldas that the haze was stratospheric:

...this whole mystery derives from a cloud equally extended in the upper part of the atmosphere, from some vapours above the horizon, and from the refraction that the light undergoes when it enters the air mass. It is this that explains the weak silvery sun; the red, the blue and the green; and it is this that explains the cold, the ice and all other features of this phenomenon that has so alarmed those of a timid disposition.

Note that the term stratospheric was only introduced to meteorology at the start of the 20th century, however Caldas demonstrated his awareness that the atmosphere consisted of layered zones, and that the haze was concentrated "in the upper part of the atmosphere". Caldas also makes no reference to either a fog or an unpleasant smell, which are common descriptions for tropospheric dry fogs caused by volcanic eruptions (usually the acidic fumes are concentrated near the ground surface and are commonly associated with distinctive odours; Grattan and Pyatt, 1999). Troposphere dry fogs are also typically unstable, being dispersed by rain or wind, and found close to the volcanic source (Camuffo and Enzi, 1994; Grattan and Pyatt, 1999; Longo et al., 2010). The upper atmospheric cloud described by Caldas, in contrast, was observed for more than 2 months across Colombia, without noticeable alteration or dispersal ("This veil has been constant both by the day and by night..."). Such stability is consistent with the interpretation of a stratospheric aerosol layer caused by an explosive volcanic eruption, and the effects match
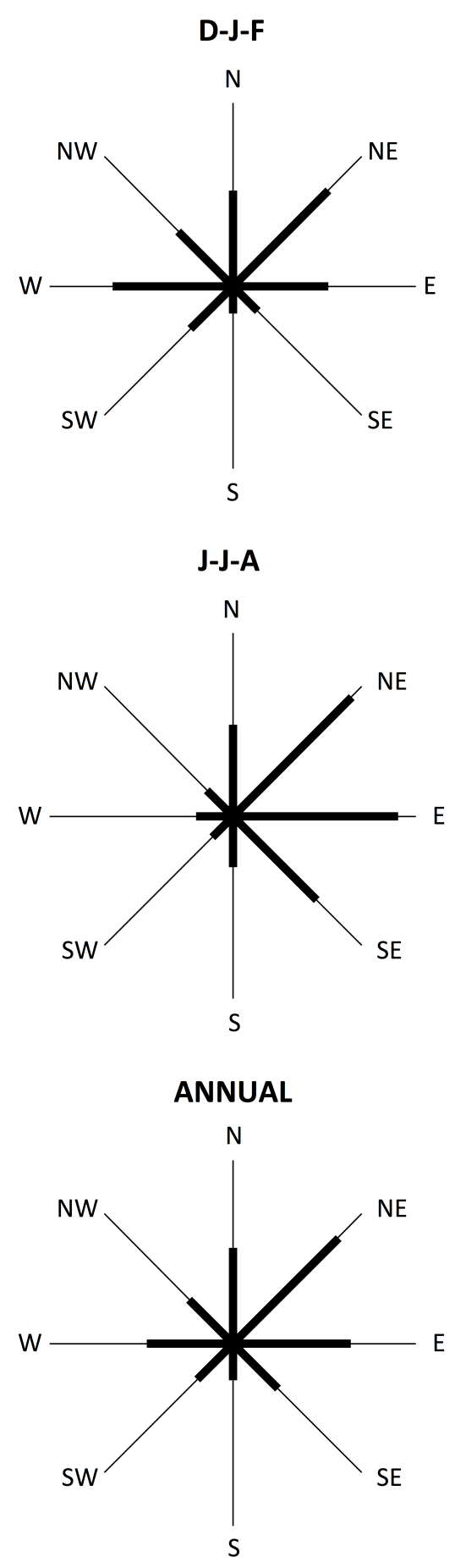

Figure 3. Wind direction at "El Dorado" Observatory in Bogotá, 1977-2001 (IDEAM and Fondo de Prevención y Atención de Emergencias, 2007). Top wind rose shows average wind direction for December to February (i.e. the months when the veil and southerly winds were reported by Caldas in Bogotá). Middle wind rose shows average wind direction for June to August, when the Inter Tropical Convergence Zone (ITCZ) is located to the north of Colombia, and lower wind rose is the annual average. 
those famously documented following the tropical stratospheric eruptions of both Tambora (Oppenheimer, 2003) and Krakatau (Symons, 1888). Similarly the astronomical consequences of the upper level haze described by Caldas ("The stars of the first, second and even the third magnitude have appeared somewhat dimmed, and those of the fourth and fifth have completely disappeared, to the observer's naked eye.") are identical to descriptions by astronomers impacted following the Krakatau eruption:

Dr. Krone noticed that at midnight the haze obscured all stars below the 4th and 5th magnitude, and Mr. Winlock reports [in Science (1884), vol. 4, 94-95: "Stars of the 3rd or 4th magnitude, which have frequently been seen on a good observing day, it is almost useless to try for now. The phenomenon is evidently not local". (Archibald in Symons, 1888, p. 225).

Coincident with the persistent upper atmospheric cloud, Caldas documented anomalously cold overnight land surface temperatures, evidenced by frequent early morning frost and frost-damaged vegetation. While modern meteorological observations in Bogotá show that frosts are more likely to occur between December and February (Fig. 2), they are rare events, with on average, only three a year (Márquez et al., 2008). Thus, it can be inferred from Caldas' document that the cold episode of December 1808 to February 1809 was unusual, and the number of frost days was atypically high. Moreover, radiative frosts typically occur during clear nights. Frosts are not associated with high non-volcanic clouds, cirrostratus nebulosus, because these clouds trap outgoing longwave radiation emitted from the Earth's surface at night (Schneider, 1972; Liou, 1986). A volcanic aerosol veil, on the other hand, causes a negative temperature anomaly by reducing incoming short-wave radiation (Robock, 2000). Further evidence that the veil observed in Bogotá was not an ordinary water vapour cloud comes from Caldas' observation that no coronas or halos were visible. Coronas are caused by refraction of sunlight by ice crystals, and are commonly reported when there is a water vapour veil (Liou, 1986). Following the Krakatau eruption, Archibald (in Symons 1888, p. 238) also notes "the remarkable absence of notice of the corona all over the northern parts of South America" and summarizes that this absence was typical of observations across the tropics where the volcanic aerosol layer was most concentrated.

The equatorial location of the 1808 stratospheric aerosol veil, and its extension into both the Northern (Bogotá and northern areas of Colombia) and Southern Hemispheres (Lima, Peru; Fig. 1), is consistent with a tropical source for the Unknown eruption, and the single event interpretation of the bi-polar ice core sulfate records (e.g Dai et al., 1991; Mosley-Thompson et al., 2003, Cole-Dai et al., 2009). If the erupting volcano was located in either hemisphere outside of the tropics, then the stratospheric aerosols would have been confined in that hemisphere, without reaching the tropics and crossing the equator. Furthermore, it is significant that the twilight glows described by Unanue in Lima $\left(12^{\circ} \mathrm{S}\right)$ are not discussed by Caldas in Bogotá $\left(4^{\circ} \mathrm{N}\right)$ within his list of detailed observations. This missing evidence also supports a tropical volcanic origin because it suggests that the aerosol layer released by the Unknown eruption of 1808 was too thick from the outset to produce twilight glows over equatorial latitudes. A detailed analysis of the chronology and geographic extent of twilight glow observations followed the Krakatau eruption in the Royal Society report on the event (Ed. Symons, 1888). Importantly, Russell (1888) and Archibald (1888) chronicle first the appearance, and then disappearance, of the observed glows over a timescale of several months at any one location, with later reports of the phenomenon from increasingly higher latitudes. For example, 6 days after the 27 August 1883 Krakatau eruption "a long belt of vaporous sky" was observed at Medellín $\left(6.24^{\circ} \mathrm{N}\right.$, $75.58^{\circ} \mathrm{W}$ ), Colombia, "in connection with coloured suns and glows in that part of South America" (Archibald, in Symons, 1888, p. 220). Apart from this initial report, which accompanied the leading edge of the aerosol cloud, reports of glows are highlighted instead for their notable absence within the equatorial zone where the aerosol layer was thickest (Archibald, in Symons, 1888). Within 6 weeks of the Krakatau eruption sunset glows identical to Unanue's description from mid-December 1808 were observed across all longitudes (outside the equatorial band) between $30^{\circ} \mathrm{N}$ and $45^{\circ} \mathrm{S}$, as the aerosol layer dispersed (Archibald, in Symons, 1888). For example, "Very strong glows, as never before seen" were reported from Arequipa $\left(16.4^{\circ} \mathrm{S}\right)$, Peru ("Met. Zeitschrift" cited by Russell in Symons 1888, p. 289) starting 1 month after the Krakatau 27 August 1883 event.

Thus, although we can place the Unknown eruption within the tropics, the exact location of the volcano responsible for the eruption remains unresolved. We can say, however, that it is unlikely to have been in Latin America. We base this conclusion on two observations. First, we expect that such a large volcanic eruption would have been recorded in the Spanish colonial archive, given both the number and quality of scientific observations in many parts of South, Central and North America, including records of numerous smaller volcanic eruptions (Feldman, 1993). Second, there is no apparent anomaly in the rate of particle deposition in the Quelccaya ice core record $\left(\right.$ Peru; $13.93^{\circ} \mathrm{S}, 70.83^{\circ} \mathrm{W}$ ), in contrast to the obvious ash layer deposited from the 1600 Huaynaputina (Peru) eruption (Thompson et al., 1985). We also observe that, despite living in a country of frequent volcanic unrest, Caldas did not advance a hypothesis as to the source of the phenomenon he observed, limiting himself to predicting, based on his understanding of the strides made by science, that there would be a rational explanation. In fact, the link between atmospheric phenomena and large volcanic eruptions was not recognized even for the 1815 Tambora eruption, as evidenced by the reaction to Roulin's 1832 account 
to the Institut de France, which are revealing for the absence of reference to this recent cataclysmic VEI 7 event, and instead make the causal link and comparison to the aerosols from the Laki (1784) eruption in Iceland:

M. Arago remarked that the mist of 1784 was not less extensive, since it was observed at the same time at Napoli di Romania and in Africa, and that its duration was still longer. This mist was remarkable for the absence of moisture; and the observations of Sennebier show that the hygrometer, when exposed to its influence, advanced towards the point of dryness. Some persons considered it as the tail of a comet, while others attributed its appearance to the eruption of a volcano, which took place about that time.

Taking into account the dates given by Caldas and Unanue, the Unknown eruption clearly occurred before 11 December 1808 , and it was unlikely to have been any earlier than late November 1808. We can constrain the eruption date to 4 December $1808 \pm 7$ days based on the precise timing given by Caldas and consistent stratospheric aerosol dispersal rates from other well-monitored tropical eruptions. Modern observations show that stratospheric aerosols are dispersed rapidly around the equator, forming a continuous layer between $10^{\circ} \mathrm{N}$ to $20^{\circ} \mathrm{S}$ within 2 weeks of an eruption, as measured by global $\mathrm{SO}_{2}$ mapping from the satellitebased Total Ozone Mapping Spectrometer following the El Chichón (1982) and Pinatubo (1991) eruptions (Bluth et al., 1992). A similar rapid rate of dispersal was documented after the 1883 Krakatau eruption (Symons, 1888), with a "blue sun" first reported in Bogotá just 7 days after Krakatau erupted; the volcanic aerosol layer was recorded across Latin America from Maracaibo, Venezuela $\left(11^{\circ} \mathrm{N}\right)$ to Guayaquil, Ecuador $\left(3^{\circ} \mathrm{S}\right)$ on the same day (Russell, in Symons, 1888, p. 276). An eruption date for the Unknown of early December 1808 agrees with the tentative estimate of February 1809 \pm 4 months calculated by Cole-Dai et al. (2009) from the timing of elevated sulfate concentrations in well-dated ice core layers from late 1809 followed by an $\sim 19$ month period of deposition at both poles (Cole-Dai et al., 2009).

The season of an eruption is a critical factor in determining when stratospheric aerosols are initially transported into the extratropics and the hemispheric partitioning of the sulfate from a low-latitude eruption (Trepte et al., 1993). For example, greater aerosol mass from the April Tambora eruption was transported into the Southern, as compared to the Northern, Hemisphere (Arfeuille et al., 2014). By comparison, ice core sulfate flux measurements indicate that the Unknown eruption deposited relatively more aerosols to the Northern Hemisphere high latitudes than the Tambora eruption: the sulfate flux signal for the Unknown eruption is $61 \%$ of that for the Tambora eruption in Greenland ice cores, compared to $45 \%$ in Antarctic ice cores (Cole-Dai et al., 2009). The asymmetry in the sulfate flux between the Unknown eruption and Tambora 6 years later can be explained by the two eruptions being almost 6 months out of phase in terms of the annual cycle. Alternatively, a high Northern
Hemisphere tropical location for the Unknown volcano could cause hemispheric differences in sulfate flux, as seen by the stronger relative deposition in Greenland than in Antarctic from Pinatubo $\left(15.13^{\circ} \mathrm{N}\right)$ relative to Tambora $\left(8.25^{\circ} \mathrm{S}\right)(\mathrm{Sigl}$ et al., 2013). Model simulations of stratospheric dispersal suggest that a greater proportion of the sulfate would be deposited in Greenland following a tropical Northern Hemisphere winter eruption relative to a summer event, although differences are within ensemble variability for a $15^{\circ} \mathrm{N}$ volcanic source and comparing January with July (Toohey et al., 2013). Importantly, the observed pattern of hemispheric bias is not reproduced by models that assume a February 1809 date of the Unknown eruption (Arfeuille et al., 2014). It is also noteworthy, in terms of the eruption timing, that Lamb (1970) identified possible evidence for volcanic haze from changes in sunset colouration seen over London in early April 1809 (although he did not calculate a Dust Veil Index value for 1809 due to the lack of a known associated volcanic eruption). This historical report occurs too early for volcanic aerosols to reach $\sim 52^{\circ} \mathrm{N}$ if the eruption was in February of the same year (i.e. within $\sim 2$ months), especially considering seasonal and hemispheric differences in global aerosol dispersal, but it is well within a realistic timescale if it is associated with a tropical eruption from early December 1808.

The tropical ocean-atmosphere system is highly sensitive to changes in radiative forcing caused by stratospheric aerosols (D'Arrigo et al., 2009). The immediate climate anomalies reported by Caldas included uncharacteristically cold temperatures leading to increased incidence and severity of frosts, which is consistent with the strong negative tropical sea surface temperature anomalies observed during 1809 from proxy sources (D'Arrigo et al., 2009) and marine and land temperature observations (e.g. Chenoweth (2001) found a pronounced cooling of $-0.84{ }^{\circ} \mathrm{C}$ in annually averaged data from $20^{\circ} \mathrm{N}-20^{\circ} \mathrm{S}$ in 1809). Caldas would also have been aware of the normal seasonality of wind and precipitation patterns in Colombia, as indicated by his time series of meteorological observations. Typically the region of intense tropical rainfall, the Inter Tropical Convergence Zone (ITCZ), is located south of the Bogotá region during the Southern Hemisphere summer months, which causes local dry conditions (Fig. 2) with a predominance of N/NE winds (Fig. 3). Caldas' report of dry weather between December 1808 and February 1809 therefore follows rainfall seasonality, although it is also consistent with a post-volcanic reduction in precipitation as observed in this region in the year following the Pinatubo eruption (negative anomaly of -2 to $-0.4 \mathrm{~mm}$ day $^{-1}$; Trenberth and Dai, 2007). In contrast, the dominant southerly wind regime in Bogotá described by Caldas during the period December 1808 to February 1809 is extremely unusual according to modern climatology for this area (Fig. 3). One possibility is that the ITCZ remained in a more northerly position at the end of 1808 , which could reflect radiative forcing from the stratospheric aerosol layer initially strengthening the meridional temperature gradients 
in the Southern Hemisphere (as seen in modelling studies of e.g. Yoshimori and Broccoli, 2008, 2009; Schneider et al., 2009). However, the description by Caldas of calm conditions in Bogotá, in addition to the southerly winds, may also be explained by more stable local conditions due to surface cooling reducing the vertical thermal gradient and decreased evaporation. Further regional-scale proxy or historical evidence is needed to confirm whether a northward displacement of the ITCZ occurred following the 1808 Unknown eruption as is suggested from the observations of Caldas.

\section{Conclusions}

We have presented evidence that a stratospheric aerosol cloud was present over Colombia from 11 December 1808 and extended into the Southern Hemisphere at least as far south as Lima, Peru, within the same week. The evidence comes from a commentary published in the Semanario del Nuevo Reyno de Granada in 1809 by the scientist Francisco José de Caldas in response to the unusual atmospheric, weather and optical phenomena being observed at the time, and a contemporaneous observation of twilight glow events recorded by the scientist Hipólito Unanue in the 1815 edition of his study on the climate of Lima (Observaciones sobre el clima de Lima). We suggest that this stratospheric aerosol layer was generated by the VEI 6 Unknown volcanic eruption previously identified and dated from bi-polar ice core sulfate anomalies and tentatively estimated as having erupted in February ( \pm 4 months) 1809 (Cole-Dai et al., 2009). Caldas and Unanue made their observations in Bogotá $\left(4^{\circ} \mathrm{N}\right)$ and Lima $\left(12^{\circ} \mathrm{S}\right)$, which means the stratospheric aerosol cloud could only have originated from a large explosive tropical eruption, as proposed by Cole-Dai et al. (1997), and not the two separate high-latitude volcanic eruptions from both hemispheres suggested by Yalcin et al. (2006) and Kurbatov et al. (2006). The dates given in the two documents restrict the actual eruption date of the Unknown eruption to between late November and early December 1808 (4 December $1808 \pm 7$ days). This estimate is based on observed rates of stratospheric aerosol dispersal from satellite monitoring (e.g. the El Chichón 1982 and Pinatubo 1991 eruptions; Bluth et al., 1992) and identical descriptions of the phenomena observed by Caldas and Unanue by observers of the after effects from the 1883 Krakatau eruption (as summarized in Symons, 1888, and Simkin and Fiske, 1984). This new eruption date means that the hemispheric partitioning of aerosol loading (e.g. Arfeuille et al., 2014) and consequently the climatic and dynamic response of the volcanic forcing will need to be reconsidered.
It is remarkable that the location of the December 1808 Unknown volcanic eruption is still a mystery given that it is a relatively recent and a very large explosive event with associated global climatic impacts. It is even more extraordinary that the Caldas and Unanue observations are the first eyewitness accounts of its indirect atmospheric effects to have been identified. The political environment on both sides of the Atlantic at the beginning of the 19th century may explain the absence of documentation in the historical record for this recent eruption despite its intensity. The eruption coincided with the Napoleonic Wars in Europe, the Peninsular War in Spain, and with political developments in Latin America that would lead, between 1810 and 1825, to the independence of almost all of Spain's American colonies. It is possible that these circumstances meant that, in Europe and Latin America at least, the attention of individuals who might otherwise have provided us with a record of unusual meteorological or atmospheric effects simply turned to military and political matters, as suggested by the content of both official correspondence and the periodical press in Spain and its colonies during these critical years. Thus Caldas and Unanue's reports may be exceptional in their description of the atmospheric and meteorological effects of the Unknown eruption of 1808. 


\section{Appendix A}

\section{Translation in English of the article written by Francisco José de Caldas}

"Meteorological News" (published in Semanario del Nuevo Reyno de Granada), in Eduardo Posada (Ed.), Obras de Caldas (Bogotá: Imprenta Nacional, 1912), 347-50.

As of 11 December of last year, the disk of the sun has appeared devoid of irradiance, its light lacking that strength which makes it impossible to observe it easily and without pain. Its natural fiery colour has changed to that of silver, so much so that many have mistaken it for the moon. This phenomenon is very noticeable at sunrise, and particularly when the sun sets. When [the sun] is at its zenith, it shines more brightly and cannot be looked at with the naked eye. Near the horizon, it has been seen to take on a light rosy hue, [or] a very pale green, or a bluey-grey close to that of steel. We have experienced very cold mornings, far colder than should be the case in this city, given its altitude and geographic location. Many mornings the fields have been covered in ice, and we have all seen trees and other particularly sensitive crops damaged by frost. The whole vault of the sky has been covered by a light cloud as widespread as it is transparent. The blue of the sky has corresponded to the lowest degrees of the cyanometer, and some days it has appeared to be truly white. [Also] missing have been the emphatic coronas which are so frequently seen around the sun and the moon when those clouds that meteorologists know by the name of veil are present. The stars of the first, second and even the third magnitude have appeared somewhat dimmed, and those of the fourth and fifth have completely disappeared, to the observer's naked eye. This veil has been constant both by the day and by night, the weather has been dry, and, intermittently, the southerly winds have been dominant, followed by periods of considerable calm.

This phenomenon has been observed in Pasto, in Popayán, in Neiva, in Santa Marta, in Tunja and no doubt throughout the entire Viceroyalty. To a physicist it would not be at all surprising were it to be seen in all countries located within the tropics.

Some have thought this phenomenon to be unique, extraordinary, and almost beyond the laws of nature, and the common people have taken it as a sure portent of great calamities [to come]. So many have consulted me, and so many have I had to reassure! The need to allay everyone's [anxiety] regarding a phenomenon that is not in the least extraordinary, and that conforms in all senses to the soundest principles of physics, has obliged me to fill [these] two pages in our Semanario, to explain that this whole mystery derives from a cloud that extends across the upper part of our atmosphere, from some vapours above the horizon, and from the refraction that the light undergoes when it enters the air mass. It is this that explains the weak silvery sun; the red, the blue and the green; and it is this that explains the cold, the ice, and all other features of this phenomenon that has so alarmed those of a timid disposition. I have seen the same sky a thousand times, and a thousand times I have had to remove the lenses from the quadrants, and from the telescope itself, the opaque or coloured glasses that temper the brightness of the sun's light in order to see its disk with clarity. History, moreover, records similar phenomena occurring in the past. Throughout the year 1673, during the reign of Philip IV, the sun appeared darkened and with an ashy hue in Cologne, Ulm and Heidelberg, and in all of Europe. Astrologers of the time, that is to say the prophets of doom, announced great things [to come], the common people and the ignorant feared [the worst]; the years passed; in the natural and the political worlds, things went on as normal; time itself disabused the concerned, and showed that the darkness of the sun was down to nothing more than an atmospheric phenomenon, extraordinary only in the sense that it was unusual. Why, then, should we be afraid? Why should we be alarmed by the effects of some vapours, by illusions created by our own senses, by inflexions of light, and by a thousand different circumstances that come together, appear and disappear like smoke, without there ever having been disastrous consequences?

NOTE: The history of physics is full of extraordinary phenomena, which seem astonishing and almost supernatural at first sight, but which turn out when subjected to critical examination by a real physicist to be ordinary phenomena, their causes well-known. The aurora borealis, that ocean of fire swimming above our heads: bars, plumes, zigzags, fountains, armies of men, and all the phantoms that the most vivid imagination can conjure up are these not down to nothing greater nor more unusual than a transparent cloud that obstructs the sun's brilliance? Specular cloud [formations], blood rain, rocks falling from the sky, parhelions, paraselenae which look like newly created celestial bodies, coronas, the ox eye which fill the hottentots with horror and fright, the tremendous ebb and flow of the [bore] tides at the mouth of the Amazon River, whirlpools and waterspouts, etc.: are these not more terrible, more extraordinary, and 
more fascinating than the phenomenon which we have been observing these last two months? As our knowledge increases, as physics and the other sciences break new ground, and as people become enlightened, what once seemed marvellous, and manifestations [of natural phenomena] that formerly filled them with terror and fear, become familiar and common. Let us open the annals of history: on each page we will read how some peoples devised extraordinary and cruel [forms of] penitence; how others submerged themselves in water, how others cried, and how others feared that the sun would be destroyed when its disk was eclipsed by the opaque body of the moon. Not even the Greeks, that wise and inventive civilization, were exempt from this [kind of] puerile fear. We know that the great Pericles would have lost a naval battle had he not explained to the pilot of his vessel the natural and simple cause behind the sun becoming obscured. Thanks to astronomers, mankind has shaken off this preoccupation and this fear. When we are as enlightened about other phenomena as we are about eclipses, then we will look on the opacity of the sun and the loss of its rays as calmly as we do a rainbow after a storm.

\section{Original text in Spanish of the article written by Francisco José de Caldas}

"Noticias Meteorológicas" (published in Semanario del Nuevo Reyno de Granada), in Eduardo Posada (Ed.), Obras de Caldas (Bogotá: Imprenta Nacional, 1912), 347-50.

Desde el día 11 de Diciembre del año último se comenzó a observar el disco del sol desnudo de irradiación y de aquella fuerza de luz que impide mirarlo con tranquilidad y sin dolor. El color de fuego que le es natural se ha cambiado en el de plata, hasta el punto de equivocarlo muchos con la luna. Este fenómeno es muy notable al nacer, y principalmente al ponerse este astro. Cuando corre la mitad del cielo, su luz es más viva y no permite mirársele a ojo desnudo. En las cercanías del horizonte se le ha visto teñido de un color de rosa muy ligero, de un verde muy claro o de un azulado gris que se acerca al del acero. Se ha sentido generalmente por las mañanas un frío pungente y muy superior al que exigen la altura y posición geográfica de esta capital. Muchos días ha amanecido el campo cubierto de hielo, y todos hemos visto quemados los árboles y demás vegetales que por su organización son demasiado sensibles a este meteoro. Toda la bóveda del cielo se ha visto cubierta de una nube muy ligera, igualmente extendida y transparente. El azul del cielo ha tocado en los primeros grados del cianómetro, y algunos días se ha visto de un verdadero blanco. Han faltado las coronas enfáticas que se observan con tanta frecuencia alrededor del sol y de la luna cuando existen aquellas nubes que los meteorologistas conocen con el nombre de velo. Las estrellas de primera, de segunda y aun de tercera magnitud se han visto algo obscurecidas, y absolutamente han desaparecido las de cuarta y quinta, a la simple vista del observador. Este velo ha sido constante tanto de día como de noche, el tiempo ha sido seco y han reinado los vientos del Sur por intervalos, sucediéndoles calmas muy considerables.

Este fenómeno se ha observado en Pasto, en Popayán, en Neiva, en Santa Marta, en Tunja y seguramente en toda la extensión del Virreinato. Nada tendría de extraño a los ojos del físico que se observase igualmente en todos los países situados dentro de los trópicos.

Algunos han creído que este fenómeno es único, extraordinario y casi fuera de las leyes comunes de la naturaleza, y el vulgo sencillo lo ha tomado como indicio seguro de grandes calamidades. ¡Cuántos me han consultado y a cuántos he tenido que serenar! La tranquilidad de todos sobre un objeto que nada tiene de extraordinario, y que en todas sus partes está conforme con los principios más sanos de la verdadera física, me han obligado a llenar dos páginas de nuestro Semanario, diciendo que todo el misterio consiste en una nube extendida igualmente en la región superior de nuestra atmósfera, en algunos vapores del horizonte y en las refracciones que sufre la luz al entrar en la masa de aire. De aquí el sol lánguido y de color de plata; de aquí el rojo, el azul, el verde; de aquí el frío, los hielos y todo lo que constituye el fenómeno que ha alarmado a los espíritus débiles. Mil veces he observado la misma disposición en el cielo, y mil veces he tenido que desnudar los anteojos de los cuartos de círculo y el telescopio mismo de los vidrios opacos o de color que templan la vivacidad de la luz, para poder observar el disco del sol con claridad. Por otra parte, la historia nos conserva la memoria de semejantes meteoros. En el reinado de Felipe IV, en todo el año de 1673, el sol se vio en Colonia, en Ulma, en Heidelberg y en toda la Europa obscurecido y de color de ceniza. Los astrólogos de aquella edad, es decir, los profetas fanáticos de la suerte del género humano, anunciaron grandes cosas; el vulgo y los ignorantes temieron; los años pasaron; las cosas naturales y políticas se mantuvieron en el estado que exigían las circunstancias; el tiempo desengañó a los preocupados y manifestó que la obscuridad del sol no era otra cosa que un meteoro que no tenía 
más de extraordinario que el ser raro. ¿Porqué pues hemos de temer? ¿Porqué nos hemos de afligir por unas apariencias producidas por vapores, por ilusiones de nuestros sentidos, por inflexiones de la luz y por otras mil circunstancias que se combinan, que varían, que suceden y desaparecen como el humo, sin que jamás hayan tenido funestas consecuencias?

NOTA: La historia de la física está llena de fenómenos extraordinarios y que al primer aspecto llevan consigo todos los caracteres de asombrosos y casi sobrenaturales; pero sujetos al examen detenido y profundo del verdadero físico, no son otra cosa que fenómenos regulares y de causas conocidas. La aurora boreal, ese océano de fuego nadando sobre nuestras cabezas, barras, plumas, ziszás, fuentes, ejércitos y todas las fantasmas que puede suministrar la imaginación más viva, ¿no tienen más de grande y de raro que una nube transparente que le quita sus resplandores al sol? Las nubes especulares, las lluvias de sangre, de piedra, los parhelios y las paraselenas en quienes parece se ha obrado una nueva creación de los cuerpos más brillantes del universo, las coronas enfáticas, el ojo del buey que llena de espanto y de terror a los hotentotes, el flujo y reflujo terrible de las embocaduras del Amazonas, la bomba marina, los vórtices, etc., ¿no son más terribles, más extraordinarios, más seductores que el fenómeno que ha dos meses observamos? A proporción que hacen progresos nuestros conocimientos, al paso que la física y las otras ciencias dilatan sus límites, y a proporción que los pueblos se ilustran, desaparece lo maravilloso, y las apariencias que antes los llenaban de terror y de miedo, vienen a serles familiares y comunes. Abramos los anales de la historia: en cada página leeremos que unos pueblos hacían penitencias extraordinarias y crueles, que otros se sumergían en el agua, que aquéllos lloraban, que éstos temían la ruina del astro del día, cuando su disco se ocultaba por el cuerpo opaco de la luna. Los griegos mismos, este pueblo sabio y original, no estuvieron exentos de este temor pueril. Sabemos que el gran Pericles habría perdido una batalla naval si no hubiera explicado al piloto de su nave la causa natural y sencilla de la obscuridad del sol. Gracias a los astrónomos, el género humano ha sacudido esta preocupación y este temor. Cuando estemos tan ilustrados sobre los demás fenómenos como lo estamos sobre los eclipses, entonces miraremos las opacidades del sol y la pérdida de sus rayos con la misma tranquilidad que vemos el iris después de una tormenta.

\section{Appendix B}

\section{Translation in English of the extract from Hipólito Unanue's Observaciones sobre el clima de Lima (Madrid, 1815)}

At sundown in the middle of the month of December, there began to appear towards the S.W., between cerro de los Chorrillos and the sea, an evening twilight that lit up the atmosphere. From a N.S. direction on the horizon, it rose towards its zenith in the form of a cone, [and] shone with a clear light until eight [o'clock] at night, when it faded. This scene was repeated every night until the middle of February, when it vanished.

\section{Extract from Hipólito Unanue's Observaciones sobre el clima de Lima}

A mediados del mes de Diciembre, comenzó a aparecer al S.O., entre el cerro de los Chorrillos y el mar al ponerse el Sol, un crepúsculo vespertino que iluminaba la atmósfera: lanzábase del horizonte N.S. hasta el cenit en forma de cono, brillaba con luz clara hasta las ocho de la noche en que se extinguía; y esta escena se renovaba todas las noches hasta mediados de Febrero en que desapareció.

\section{Appendix C}

\section{Extract from The New Monthly Magazine and Literary Journal (1832, 170-171, Part 3, Historical Register, London, published for Henry Colburn by Richard Bentley)}

Atmospherical Phenomena in New Grenada.

At a recent sitting of the French Institute, M. Roulin communicated some curious particulars relative to an unusual condition of the atmosphere observed in New Grenada [Granada]. From the 11th of December 1808, to the end of January 1809 , the disk of the sun at his rising appeared pale, and totally divested of its dazzling splendour, so that it was often mistaken for the moon. However, after gaining a slight elevation, it reassumed its ordinary aspect. Both in the morning and evening, it often appeared tinged with a slight shade of rose colour or light green, and sometimes of a bluish grey, nearly resembling the hue of steel. The cold, during the whole of this time, was more sensibly felt than general; and frequently in the morning the plains in the neighbourhood of Bogota were covered with a hoar frost, which nipped the 
tender shoots of plants, a circumstance before unknown in this district within the memory of man. The sky was constantly clothed with a transparent haze, uniformly extended, and continuing during the day as well as the night. This produced none of those coloured halos, which are generally served on such occasions surrounding the sun and moon. It concealed all stars below the fourth magnitude. The air was constantly free from moisture, and generally calm; and the winds which blew at short intervals, came always from the South. This phenomenon was observed at Pasto Popayan, Neyba [Neiva] Tunja, and Santa Martha [Marta]; that is, from the first to the twelfth degree of south latitude. M. Arago remarked that the mist of 1784 was not less extensive, since it was observed at the same time at Napoli di Romania and in Africa, and that its duration was still longer. This mist was remarkable for the absence of moisture; and the observations of Sennebier show that the hygrometer, when exposed to its influence, advanced towards the point of dryness. Some persons considered it as the tail of a comet, while others attributed its appearance to the eruption of a volcano, which took place about that time. 
Acknowledgements. This work was supported by a joint U. Bristol postgraduate scholarship and La Caixa Scholarship to A. GuevaraMurua, a Royal Society Fellowship to A. C. Rust, a RCUK Academic Fellowship to E. J. Hendy, and the AXA Research Fund (to K. V. Cashman). Simon Powell kindly produced Fig. 1. We thank R. Allan, J. Cole-Dai, M. Toohey and C. Zerefos for their constructive comments to improve the manuscript. The authors also acknowledge support from the Cabot Institute, University of Bristol.

Edited by: S. Brönnimann

\section{References}

Appel, J. W.: Francisco José de Caldas: a scientist at work in Nueva Granada, T. Am. Philos. Soc., 84, 1-154, 1994.

Archibald, E. D.: The sky-haze and some of its effect, Section I in Part IV, Russell, F. A. R. and Archibald, E. D.: On the unusual optical phenomena of the atmosphere, 1883-6, including twilight effects, coronal appearances, sky haze, coloured suns, moons, edited by: Symons, G. J., The eruption of Krakatoa: and subsequent phenomena, Report of the Krakatoa committee of the Royal Society, Trübner \& Company, London, 199-218, 1888.

Arfeuille, F., Weisenstein, D., Mack, H., Rozanov, E., Peter, T., and Brönnimann, S.: Volcanic forcing for climate modeling: a new microphysics-based data set covering years 1600-present, Clim. Past, 10, 359-375, doi:10.5194/cp-10-359-2014, 2014.

Bluth, G. J., Doiron, S. D., Schnetzler, C. C., Krueger, A. J., and Walter, L. S.: Global tracking of the $\mathrm{SO}_{2}$ clouds from the June, 1991 Mount Pinatubo eruptions, Geophys. Res. Lett., 19, 151154, 1992.

Briffa, K. R., Jones, P. D., Schweingruber, F. H., and Osborn, T. J.: Influence of volcanic eruptions on Northern Hemisphere summer temperature over the past 600 years, Nature, 393, 450-455, 1998.

Caldas, F. J.: Obras de Caldas, Ed. E. Posada, Bogotá, Imprenta Nacional, 1912.

Camuffo, D. and Enzi, S.: Chronology of "dry fogs" in Italy, 13741891, Theor. Appl. Climatol., 50, 31-33, 1994.

Chenoweth, M.: Two major volcanic cooling episodes derived from global marine air temperature, AD 1807-1827, Geophys. Res. Lett., 28, 2963-2966, 2001.

Cole-Dai, J., Mosley-Thompson, E., and Thompson, L. G.: Annually resolved southern hemisphere volcanic history from two Antarctic ice cores, J. Geophys. Res., 102, 16761-16771, doi:10.1029/97JD01394, 1997.

Cole-Dai, J., D. Ferris, A. Lanciki, J. Savarino, M. Baroni, and Thiemens M. H.: Cold decade (AD 1810-1819) caused by Tambora (1815) and another (1809) stratospheric volcanic eruption, Geophys. Res. Lett., 36, L22703, doi:10.1029/2009GL040882, 2009

Crowley, T. J., Zielinski, J. G., Vinter, B., Udisti, R., Kreutz, K., Cole-Dai, J., and Castellano, E.: Volcanism and the Little Ice Age, PAGES Newslett., 16, 22-23, 2008.

Crowley, T. J. and Unterman, M. B.: Technical details concerning development of a $1200 \mathrm{yr}$ proxy index for global volcanism, Earth Syst. Sci. Data, 5, 187-197, doi:10.5194/essd-5-187-2013, 2013.

Cushman, G. T.: Humboldtian Science, Creole meteorology, and the discovery of human-caused climate change in South America, Osiris, 26, 16-44, 2011.
Dai, J., Mosley-Thompson, E., and Thompson, L. G.: Ice core evidence for an explosive tropical volcanic eruption 6 years preceding Tambora, J. Geophys. Res.-Atmos., 96, 17361-17366, 1991.

D'Arrigo, R., Wilson, R., and Tudhope, A.: The impact of volcanic forcing on tropical temperatures during the past four centuries, Nat. Geosci., 2, 51-56, 2009.

Deirmendjian, D.: On Volcanic and Other Particulate Turbidlty Anomalies, Adv. Geophys., 16, 267-296, 1973.

Eddy, J. A.: The Maunder Minimum, Science, 192, 1189-1202, 1976.

Feldman, L. H.: Mountains of Fire, Lands that Shake, Calver City, CA, Labyrinthos, 1993.

Gao, C., Robock, A., and Ammann, C.: Volcanic forcing of climate over the past 1500 years: An improved ice core-based index for climate models, J. Geophys. Res., 113, D23111, doi:10.1029/2008JD010239, 2008.

Glick, T. F.: Science and Independence in Latin América (with special reference to New Granada), The Hispanic Am. Hist. Rev., 71, 307-334, 1991.

Graf, H.-F.: Arctic radiation deficit and climate variability, Clim. Dyn., 7, 19-28, 1992.

Grattan, J. P. and Brayshay, M. B.: An amazing and portentous summer: Environmental and social responses in Britain to the 1783 eruption of an Iceland Volcano, Geogr. J., 161, 125-134, 1995.

Grattan, J. P and Pyatt, F. B: Volcanic eruptions dry fogs and the European palaeoenvironmental record: localised phenomena or hemispheric impacts?, Global Planet. Change, 21, 173-179, 1999.

Hamill, P., Jensen, E. J., Russell, P. B, and Bauman, J. J.: The life cycle of stratospheric aerosol particles, Bull. Am. Meteorol. Soc., 78, 1395-1410, 1997.

Holton, J. R., Haynes, P. H., McIntyre, M. E., Douglass, A. R., Rood, R. B., and Pfister, L.: Stratosphere-troposphere exchange, Rev. Geophys., 33, 403-439, 1995.

Humboldt, A. V., Kutzinski, V. M., and Ette, O. (Eds.): Political Essay on the Island of Cuba: A Critical Edition, Chicago University Press, Chicago and London, 496 pp., 2011.

IDEAM and Fondo de Prevención y Atención de Emergencias: Estudio de la caracterización climática de Bogotá y Cuenca alta del río Tunjuelo, 118pp. Milenio, Bogotá, 2007.

Jones, P. D., Briffa, K. R., and Schweingruber, F. H.: Tree-ring evidence of the widespread effects of explosive volcanic eruptions, Geophys. Res. Lett., 22, 1333-1336, 1995.

Kurbatov, A. V., Zielinski, G. A., Dunbar, N. W., Mayewski, P. A., Meyerson, E. A., Sneed, S. B., and Taylor, K. C.: A 12000 year record of explosive volcanism in the Siple Dome Ice Core, West Antarctica, J. Geophys. Res., 111, D12307, doi:10.1029/2005JD006072, 2006.

Lamb, H. H.: Volcanic dust in the atmosphere; with a chronology and assessment of its meteorological significance, Phil. Trans. R. Soc. Lond. A, 266, 425-533, 1970.

Legrand, M. R. and Delmas, R. J.: A 220-year continuous record of volcanic $\mathrm{H}_{2} \mathrm{SO}_{4}$ in the Antarctic Ice-Sheet, Nature, 27, 671-676, 1987.

Lilienfeld, P.: A blue sky history, Opt. Photonics News, 15, 32-39, 2004.

Liou, K.-N.: Influence of cirrus clouds on weather and climate processes: A global perspective, Mon. Weather Rev., 114, 11671199, 1986. 
Longo, B. M., Yang, W., Green, J. B., Crosby, F. L., and Crosby, V. L.: Acute health effects associated with exposure to volcanic air pollution (vog) from increased activity at Kilauea Volcano in 2008, J. Toxicol. Env. Health, Part A, 73, 1370-1381, 2010.

Márquez, R. M., González, Y., and Hurtado, G.: Las heladas en Colombia, Instituto de Hidrología, Meteorología y Estudios Ambientales, Bogotá, IDEAM-METEO/003-2008, 50 pp., 2008.

Moore, J. C., Narita, H., and Maeno, N.: A continuous 770-year record of volcanic activity from East Antarctica, J. Geophy. Res., 96, 17353-17359, 1991

Mosley-Thompson, E., Mashiotta, T. A., and Thompson, L. G.: High resolution ice core records of late Holocene volcanism: Current and future contributions from the Greenland PARCA core, Geophys. Monogr. Ser., 139, 153-164, 2003.

Nieto, M., Castaño, P., and Ojeda, D.: 'El influjo del clima sobre los seres organizados' y la retórica ilustrada en el Semanario del Nuevo Reyno de Granada, Hist. Crit., 30, 91-114, 2005.

Nieto Olarte, M.: Scientific instruments, Creole science, and natural order in the New Granada of the early nineteenth century, J. Spanish Cult. Stud., 8, 235-252, 2007.

Oman, L., Robock, A., Stenchikov, G., Schmidt, G. A., and Ruedy, R.: Climatic response to high-latitude volcanic eruptions, J. Geophys. Res.-Atmos., 110, D13103, doi:10.29/2004JD005487, 2005.

Oppenheimer, C.: Climatic, environmental and human consequences of the largest known historic eruption: Tambora volcano (Indonesia) 1815, Prog. Phys. Geog., 27, 230-259, 2003.

Plumb, R. A.: A tropical pipe model of stratospheric transport, J. Geophys. Res., 101, 3957-3972, 1996.

Robock, A.: Volcanic eruptions and climate, Rev. Geophys., 38, 191-219, 2000.

Russell, F. A. R.: General list of dates of first appearance of all the optical phenomena, Section II in Part IV, Russell, F. A. R. and Archibald, E. D.: On the unusual optical phenomena of the atmosphere, 1883-6, including twilight effects, coronal appearances, sky haze, coloured suns, moons, edited by: Symons, G. J., The eruption of Krakatoa: and subsequent phenomena, Report of the Krakatoa committee of the Royal Society, Trübner \& Company, London, 263-311, 1888.

Schneider, D. P., Ammann, C. M., Otto-Bliesner, B. L., and Kaufman, D. S.: Climate response to large, high-latitude and low-latitude volcanic eruptions in the Community Climate System Model, J. Geophys. Res.-Atmos., 114, D15101, doi:10.1029/2008JD011222, 2009.

Schneider, S. H.: Cloudiness as a Global Climatic Feedback Mechanism: The Effects on the Radiation Balance and Surface Temperature of Variations in Cloudiness, J. Atmos. Sci., 29, 1413-1422, 1972.

Sigl, M., McConnell, J. R., Layman, L., Maselli, O., Pasteris, D., McGwire, K., Dahl-Jensen, D., Steffensen, J. P., Vinther, B. M., Edwards, R., Mulvaney, R., and Kipfstuhl, S.: A new bipolar ice core record of volcanism from WAIS Divide and NEEM and implications for climate forcing of the last 2000 years, Geophys. Res. Atmos., 118, 1151-1169, 2013.

Simkin, T. and Fiske, R. S.: Krakatau 1883. The volcanic eruption and its effects, Smithsonian Institution Press, Washington DC, 464 pp., 1984.
Stothers, R. B.: The great Tambora eruption in 1815 and its aftermath, Science, 224, 1191-1198, 1984.

Stothers, R. B.: The great dry fog of 1783, Clim. Change, 32, 79-89, 1996.

Stothers, R. B.: Volcanic dry fogs, climate cooling, and plague pandemics in Europe and the Middle East, Clim. Change, 42, 713723, 1999.

Stothers, R. B. and Rampino, M. R.: Historic volcanism, European dry fogs, and Greenland acid precipitation, 1500 BC to AD 1500, Science, 222, 411-413, 1983.

Symons, G. J. (Ed): The eruption of Krakatoa: and subsequent phenomena, Report of the Krakatoa committee of the Royal Society, Trübner \& Company, London, 627 pp., 1888.

Thompson, L. G., Mosley-Thompson, E., Bolzan, J. F., and Koci, B. R.: A 1500 year record of tropical precipitation recorded in ice cores from the Quelccaya Ice Cap, Peru, Science, 229, 971-973, 1985.

Thordarson, T. and Self, S.: Atmospheric and environmental effects of the 1783-1784 Laki eruption: A review and reassessment, J. Geophy. Res. Atmos., 108, 4011, doi:10.1029/2001JD002042, 2003.

Toohey, M., Krüger, K., Niemeier, U., and Timmreck, C.: The influence of eruption season on the global aerosol evolution and radiative impact of tropical volcanic eruptions, Atmos. Chem. Phys., 11, 12351-12367, doi:10.5194/acp-11-12351-2011, 2011.

Toohey, M., Krüger, K., and Timmreck, C.: Volcanic sulfate deposition to Greenland and Antarctica: A modeling sensitivity study, J. Geophys. Res. Atmos., 118, 4788-4800, 2013.

Trenberth, K. E. and Dai, A.: Effects of Mount Pinatubo volcanic eruption on the hydrological cycle as an ana$\log$ of geoengineering, Geophys. Res. Lett., 34, L15702, doi:10.1029/2007GL030524, 2007.

Trepte, C. R., Veiga, R. E., and McCormick, M. P.: The poleward dispersal of Mount Pinatubo volcanic aerosol, J. Geophys. Res.Atmos., 98, 18563-18573, 1993.

Unanue, J. H.: Observaciones sobre el clima de Lima: y sus influencias en los seres organizados, en especial el hombre, Madrid, Imprenta de Sancha, 1815.

Yalcin, K., Wake, C. P., Kreutz, K. J., Germani, M. S., and Whitlow, S. I.: Ice core evidence for a second volcanic eruption around 1809 in the Northern Hemisphere, Geophys. Res. Lett., 33, L14706, doi:10.1029/2006GL026013, 2006.

Yoshimori, M. and Broccoli, A. J.: Equilibrium response of an atmosphere-mixed layer ocean model to different radiative forcing agents: Global and zonal mean response, J. Clim., 21, 43994423, 2008.

Yoshimori, M. and Broccoli, A. J.: On the link between Hadley circulation changes and radiative feedback processes, Geophys. Res. Lett., 36, L20703, doi:10.1029/2009GL040488, 2009.

Zerefos, C. S., Gerogiannis, V. T., Balis, D., Zerefos, S. C., and Kazantzidis, A.: Atmospheric effects of volcanic eruptions as seen by famous artists and depicted in their paintings, Atmos. Chem. Phys., 7, 4027-4042, doi:10.5194/acp-7-4027-2007, 2007.

Zerefos, C. S., Tetsis, P., Kazantzidis, A., Amiridis, V., Zerefos, S. C., Luterbacher, J., Eleftheratos, K., Gerasopoulos, E., Kazadzis, S., and Papayannis, A.: Further evidence of important environmental information content in red-to-green ratios as depicted in 
paintings by great masters, Atmos. Chem. Phys., 14, 2987-3015, doi:10.5194/acp-14-2987-2014, 2014.
Zimmerer, K. S.: Humboldt's nodes and modes of interdisciplinary environmental science in the andean world, Geogr. Rev., 96, 335360, 2006. 